\title{
उMR
}

\section{New chromosomal evidence for the origin of Triatoma infestans populations from Brazil}

\author{
N.P. Pereira ${ }^{1}$, K.C.C. Alevi ${ }^{1}$, J.A. Rosa ${ }^{2}$ and M.T.V. Azeredo-Oliveira ${ }^{1}$ \\ ${ }^{1}$ Laboratório de Biologia Celular, Departamento de Biologia, \\ Instituto de Biociências, Letras e Ciências Exatas, \\ Universidade Estadual Paulista "Júlio de Mesquita Filho", São José do Rio Preto, \\ SP, Brasil \\ ${ }^{2}$ Laboratório de Parasitologia, Departamento de Ciências Biológicas, \\ Faculdade de Ciências Farmacêuticas, \\ Universidade Estadual Paulista "Júlio de Mesquita Filho", Araraquara, SP, Brasil \\ Corresponding author: K.C.C. Alevi \\ E-mail: kaiochaboli@hotmail.com
}

Genet. Mol. Res. 15 (3): gmr.15038303

Received December 17, 2015

Accepted February 11, 2015

Published August 26, 2016

DOI http://dx.doi.org/10.4238/gmr.15038303

Copyright (C) 2016 The Authors. This is an open-access article distributed under the terms of the Creative Commons Attribution ShareAlike (CC BY-SA) 4.0 License.

\begin{abstract}
In this study, the karyometry of different Triatoma infestans populations from different states of Brazil was analyzed and compared with those of a population from Cochabamba. No significant differences were found between the population from Cochabamba and those from Brazil. These results are consistent with the origin of the $T$. infestans populations of Brazil by a founder effect from Cochabamba. Moreover, these findings also confirm that a founder effect occurred during the dispersal of T. infestans populations in different Brazilian states.
\end{abstract}

Key words: Chromosome measurement; Founder effect; Karyometry; Chagas disease 


\section{INTRODUCTION}

Triatoma infestans is a synanthropic species broadly distributed among triatomine in the Americas, and for a long time, considered to be the main vector species of Chagas disease in South America (Noireau et al., 1996). According to Galvão et al. (2003), this species can be found in Argentina, Bolivia, Brazil, Chile, Ecuador, Mexico, Paraguay, Peru, and Uruguay.

T. infestans originates from the Cochabamba region of central Bolivia, but is found today from central Argentina and Bolivia north to the Brazilian east coast, and the west coast of southern Peru (Schofield, 1994). In Cochabamba T. infestans can be found in silvatic habitats under rock piles, as well as in peridomestic and domestic habitats. In other locations, including Brazil, T. infestans appears to have been introduced by passive dispersal as a predominantly domestic species (Dujardin et al., 1987; Schofield, 1994).

Panzera et al. (2004) analyzed heterochromatic patterns in different populations of $T$. infestans and divided these organisms into two allopatric groups (Andean and non-Andean). Those authors observed approximately $30 \%$ variation in the amount of DNA in the two groups (with the non-Andean group having lost genetic material and heterochromatin) and suggested that non-Andean populations of T. infestans could have been established by one or a few founders that eventually lost part of their heterochromatin by random-genetic drift.

Dujardin et al. (1998) used enzymatic comparisons to demonstrate the limited genetic diversity between neighboring populations of $T$. infestans, which suggests a recent and relatively rapid dispersal of this species from its presumed Bolivian origin. The passive dispersal of T. infestans in different Brazilian states is associated with human migration (Pires et al., 1998). Those authors analyzed morphometric characters and isoenzyme patterns of two $T$. infestans populations and suggested that the genetic homogeneity observed in Brazilian and laboratory-reared colonies from Bolivia might be due to selection as a result of passive dispersion, followed by several episodes of founder effects and genetic drift.

Thus, the aim of this study was to analyze the karyometry of different populations of $T$. infestans from different states of Brazil and to compare them with a population from Cochabamba, in order to supplement our understanding of the evolutionary events associated with the dispersal of $T$. infestans in the Brazilian states.

\section{MATERIAL AND METHODS}

Ten T. infestans males from each location [Caçapava do Sul/Rio Grande do Sul (RS), Mambaí/Goiás (GO), Tanhaçu/Bahia (BA), Glória de Dourados/Mato Grosso do Sul (MS), and Cochabamba (Bolívia)] were analyzed. Each male had been assigned by the "Triatominae Insectarium" within the Department of Biological Sciences, in the College of Pharmaceutical Sciences, at São Paulo State University's Araraquara campus, São Paulo. Seminiferous tubules were shredded, smashed, and then set on a slide in liquid nitrogen. Samples were then stained using the lacto-aceto-orcein cytogenetic technique (De Vaio et al., 1985), with modifications (Alevi et al., 2012). Ten metaphases were selected for each insect, and chromosomal measurements were made according to the method described by Bardella et al. (2010).

\section{RESULTS AND DISCUSSION}

We found small differences in the size of chromosomes from different lineages

Genetics and Molecular Research 15 (3): gmr.15038303 
analyzed; however, these differences were not statistically significant (Table 1). In general, the chromosomes of these vectors retained the chromosomal characteristics described by Barth (1956).

Table 1. Mean chromosomal values at the five locations studied.
\begin{tabular}{l|c|c|c|c|c}
\hline Chromosome & Caçapava do Sul (RS) & Glória de Dourados (MS) & Mambaí (GO) & Tanhaçu (BA) & Cochabamba (Bolívia) \\
\hline Autosome 1 & $15.684 \pm 1.42$ & $15.975 \pm 1.30$ & $14.705 \pm 2.09$ & $13.158 \pm 2.49$ & $14.585 \pm 1.9)$ \\
\hline Autosome 2 & $14.187 \pm 1.54$ & $13.165 \pm 2.19$ & $12.282 \pm 1.37$ & $12.501 \pm 2.22$ & $12.705 \pm 2.4)$ \\
\hline Autosome 3 & $10.632 \pm 1.23$ & $11.568 \pm 0.95$ & $10.335 \pm 1.87$ & $11.065 \pm 1.34$ & $11.216 \pm 2.29$ \\
\hline Autosome 4 & $9.432 \pm 0.89$ & $10.100 \pm 1.08$ & $9.124 \pm 1.28$ & $11.034 \pm 2.49$ & $9.022 \pm 1.53$ \\
\hline Autosome 5 & $9.001 \pm 0.99$ & $7.140 \pm 1.07$ & $9.487 \pm 1.51$ & $8.483 \pm 1.61$ & $7.879 \pm 1.21$ \\
\hline Autosome 6 & $7.612 \pm 0.67$ & $6.965 \pm 0.87$ & $8.003 \pm 1.32$ & $7.500 \pm 0.90$ & $7.159 \pm 1.05$ \\
\hline Autosome 7 & $6.673 \pm 1.10$ & $6.984 \pm 0.63$ & $7.185 \pm 1.03$ & $7.384 \pm 1.00$ & $7.716 \pm 1.74$ \\
\hline Autosome 8 & $6.077 \pm 0.51$ & $6.786 \pm 0.60$ & $7.128 \pm 0.67$ & $6.858 \pm 1.10$ & $7.180 \pm 0.63$ \\
\hline Autosome 9 & $5.651 \pm 0.63$ & $6.320 \pm 0.74$ & $6.783 \pm 1.35$ & $7.429 \pm 1.11$ & $6.968 \pm 0.69$ \\
\hline Autosome 10 & $5.488 \pm 0.69$ & $5.974 \pm 0.85$ & $5.330 \pm 0.90$ & $5.992 \pm 0.77$ & $6.907 \pm 0.80$ \\
\hline Y & $5.161 \pm 0.85$ & $4.976 \pm 0.69$ & $5.100 \pm 1.16$ & $4.595 \pm 0.81$ & $4.907 \pm 1.08$ \\
\hline X & $4.394 \pm 0.30$ & $4.040 \pm 0.57$ & $4.533 \pm 1.24$ & $3.996 \pm 0.59$ & $3.749 \pm 0.58$ \\
\hline
\end{tabular}

Intraspecific variability and variation within populations have been detected by other means between $T$. infestans from different locations. Lent and Jurberg (1985) reported intraspecific variation in these insects by the morphological analysis of the male genital structures. Pires et al. (1998) observed variation in the external structures of the genitals and suggested that this could be used as a tool to characterize the populations studied. CalderónFernández et al. (2012) observed high variation within populations and low population variability in T. infestans through the analysis of cuticular hydrocarbon profiles. Gárcia et al. (1995) had previously used molecular techniques to analyze uniformity between allelic frequencies of populations.

Bardella et al. (2010) examined the karyometry of different species of triatomines and noted significant differences between species. Those authors analyzed the subspecies T. i. melanosoma and described the same chromosomal features that we observed for $T$. infestans, corroborating the synonymy of T. i. melanosoma for T. infestans proposed by Gumiel et al. (2003).

By means of karyometry it were not found significant differences between the population of Cochabamba (Andean) and Brazilian (non-Andean). However, these results are consistent with the origin of the T. infestans populations in Brazil from Cochabamba by a founder effect (Schofield, 1994; Pires et al., 1998). Moreover, it confirms for founder effect that also occurred during the dispersal of populations in different Brazilian states.

Homogeneity in chromosome characteristics, such as number of chromosomes, heterochromatin pattern, and disposition of $45 \mathrm{~S}$ probes, has been previously reported for different populations in Brazil (Panzera et al., 2004, 2012, 2014). However, these populations are significantly different to those from the Andean T. infestans.

Therefore, low chromosomal variation observed by karyometry in different lineages and Brazilian T. infestans of Cochabamba corroborates the hypothesis that T. infestans originated from Cochabamba, and that the dispersion of T. infestans in Brazil occurred by founder effect. We suggest that this phenomenon has allowed the colonization of different environments by this important vector of Chagas disease.

\section{Conflicts of interest}

The authors declare no conflict of interest.

Genetics and Molecular Research 15 (3): gmr.15038303 


\section{ACKNOWLEDGMENTS}

Research supported by Fundação de Amparo à Pesquisa do Estado de São Paulo (FAPESP) and Conselho Nacional de Desenvolvimento Científico e Tecnológico (CNPq).

\section{REFERENCES}

Alevi KCC, Mendonça PP, Pereira NP, Rosa JA, et al. (2012). Karyotype of Triatoma melanocephala Neiva and Pinto (1923). Does this species fit in the Brasiliensis subcomplex? Infect. Genet. Evol. 12: 1652-1653. http://dx.doi. org/10.1016/j.meegid.2012.06.011

Bardella VB, Gaeta ML, Vanzela ALL and Azeredo-Oliveira MTV (2010). Chromosomal location of heterochromatin and 45S rDNA sites in four South American triatomines (Heteroptera: Reduviidae). Comp. Cytogenet. 4: 141-149. http:// dx.doi.org/10.3897/compcytogen.v4i2.50

Barth R (1956). Estudos anatômicos e histológicos sôbre a subfamília Triatominae (Hemiptera, Reduviidae). VI. Estudo comparativo sôbre a espermiocitogênese das espécies mais importantes. Mem. Inst. Oswaldo Cruz 54: 599-623. http://dx.doi.org/10.1590/S0074-02761956000300009

Calderón-Fernández GM, Girotti JR and Juárez MP (2012). Cuticular hydrocarbon pattern as a chemotaxonomy marker to assess intraspecific variability in Triatoma infestans, a major vector of Chagas' disease. Med. Vet. Entomol. 26: 201-209. http://dx.doi.org/10.1111/j.1365-2915.2011.00978.x

De Vaio ES, Grucci B, Castagnino AM, Franca ME, et al. (1985). Meiotic differences between three triatomine species (Hemiptera:Reduviidae). Genetica 67: 185-191. http://dx.doi.org/10.1007/BF02424489

Dujardin JP, Tibayrenc M, Venegas E, Maldonado L, et al. (1987). Isozyme evidence of lack of speciation between wild and domestic Triatoma infestans (Heteroptera: Reduviidae) in Bolivia. J. Med. Entomol. 24: 40-45. http://dx.doi. org/10.1093/jmedent/24.1.40

Dujardin JP, Schofield CJ and Tibayrenc M (1998). Population structure of Andean Triatoma infestans: allozyme frequencies and their epidemiological relevance. Med. Vet. Entomol. 12: 20-29. http://dx.doi.org/10.1046/j.13652915.1998.00076.x

Galvão C, Carcavallo RU, Rocha DS and Jurberg J (2003). A checklist of the current valid species of the subfamily Triatominae Jeannel, 1919 (Hemiptera, Reduviidae) and their geographical distribution, with nomenclatural and taxonomic notes. Zootaxa 202: 1-36.

García BA, Soares Barata JM and Blanco A (1995). Enzyme polymorphism among Triatoma infestans (Hemiptera: Reduviidae) colonies. J. Med. Entomol. 32: 126-133. http://dx.doi.org/10.1093/jmedent/32.2.126

Gumiel M, Catala S, Noireau F, Rojas De Arias A, et al. (2003). Wing geometry in Triatoma infestans (Klug) and $T$. melanosoma Martinez, Olmedo and Carcavallo (Hemiptera: Reduviidae). Syst. Entomol. 28: 173-179. http://dx.doi. org/10.1046/j.1365-3113.2003.00206.x

Lent H and Jurberg J (1985). Sobre a variação intra-específica em Triatoma dimidiata (Latreille) e Triatoma infestans (Klug, 1834) (Hemiptera, Reduviidae). Mem. Inst. Oswaldo Cruz 80: 285-299. http://dx.doi.org/10.1590/S0074$\underline{02761985000300004}$

Noireau F, Brenière F, Cardozo L, Bosseno MF, et al. (1996). Current spread of Triatoma infestans at the expense of Triatoma sordida in Bolivia. Mem. Inst. Oswaldo Cruz 91: 271-272. http://dx.doi.org/10.1590/S0074-02761996000300002

Panzera F, Dujardin JP, Nicolini P, Caraccio MN, et al. (2004). Genomic changes of Chagas disease vector, South America. Emerg. Infect. Dis. 10: 438-446.http://dx.doi.org/10.3201/eid1003.020812

Panzera F, Ferreiro MJ, Pita S, Calleros L, et al. (2014). Evolutionary and dispersal history of Triatoma infestans, main vector of Chagas disease, by chromosomal markers. Infect. Genet. Evol. 27: 105-113. http://dx.doi.org/10.1016/j. meegid.2014.07.006

Panzera Y, Pita S, Ferreiro MJ, Ferrandis I, et al. (2012). High dynamics of rDNA cluster location in kissing bug holocentric chromosomes (Triatominae, Heteroptera). Cytogenet. Genome Res. 138: 56-67.http://dx.doi.org/10.1159/000341888

Pires HHR, Barbosa SE, Margonari C, Jurberg J, et al. (1998). Variations of the external male genitalia in three populations of Triatoma infestans Klug, 1834. Mem. Inst. Oswaldo Cruz 93: 479-483. http://dx.doi.org/10.1590/S0074$\underline{02761998000400011}$

Schofield CJ (1994). Triatominae - Biologia y Control. 1st edn. Eurocommunica Publications, West Sussex, U.K.

Genetics and Molecular Research 15 (3): gmr.15038303 